\title{
Percepcija djece o utjecaju videoigara
}

Prethodno priopćenje _ DOI 10.22522/cmr20190137_ primljeno 20. siječnja 2018.

UDK: 795-042.3-053.2

$003.02: 316.774$

\section{Danijel Labaš}

Hrvatski studiji, Zagreb, Hrvatska.

Email: dlabas@hrstud.hr

\section{Ines Marinčić}

Društvo za komunikacijsku i medijsku kulturu, Zagreb, Hrvatska.

Email: inesmarincic@gmail.com

\section{Alma Mujčinović}

Saatchi \& Saatchi, Zagreb, Hrvatska.

E-adresa: alma.mujcinovic@saatchi.hr

\section{Sažetak}

Od trenutka kada se u svojoj najranijoj dobi upoznaju s medijima, djeca se susreću s raznovrsnim medijskim sadržajima koji su promijenili njihov način provođenja slobodnoga vremena (Šego, 2009, str. 62), a jedan od omiljenih jest druženje i igra u virtualnome svijetu - svijetu videoigara, u kojem su izložena njihovu pozitivnom i negativnom utjecaju. Novonastale se okolnosti odražavaju na odgoj i mijenjaju ulogu roditelja, odgajatelja i nastavnika. Stoga se danas, više nego ikada, ističe potreba razvoja medijske kompetencije i medijske pismenosti među djecom i odraslima s ciljem poticanja kritičkog razmišljanja o medijskim sadržajima te odgovorne i učinkovite uporabe medija. U radu se prikazuju rezultati istraživanja provedenog u razdoblju između siječnja i ožujka 2016. godine među 630 djece u dobi od 10 do 15 godina u trima osnovnim školama na području Grada Zagreba i Zagrebačke županije. Za prikupljanje rezultata korištena je metoda ankete. Rezultati ovoga istraživanja pružaju uvid u odnos djece prema videoigrama, njihovim preferencijama pri odabiru videoigara i percepciji njihova sadržaja i funkcije, a usto mogu poslužiti kao korisni podaci za razumijevanje osobitosti videoigara te kao poticaj na razmišljanje o aktivnom uključivanju i korištenju edukativnih videoigara u procesu učenja.

Ključne riječi: djeca, videoigre, utjecaj, edukacija, medijska pismenost 


\section{1.}

Računala, tableti i pametni telefoni zauzeli su važno mjesto u životima djece i adolescenata (Šego, 2009, str. 62), a sudjelovanje u igranju videoigara postalo je „najbrže rastući oblik ljudske rekreacije“ (Przybylski i sur., 2006, str. 347). Djeca su promijenila način na koji provode svoje slobodno vrijeme (Šego, 2009, str. 62), a jedan od omiljenih načina jest druženje i igra u virtualnome svijetu - svijetu videoigara što postavlja brojna pedagoška, ali i etička pitanja (Wimmer, 2014, str. 274-275).

Prema rezultatima istraživanja provedenog 2013. godine, Hrvati uz videoigre provedu 612 sati godišnje. Drugim riječima, ukupno oko 25 dana neprekidnog igranja videoigara bez pauza za jelo, piće, spavanje i ostale svakodnevne potrebe (Tvornica istraživanja, 2014). Naime, posljednjih nekoliko desetljeća industrija videoigara ubrzano se razvija i raste unutar zabavne industrije ostavljajući u sjeni filmsku i glazbenu industriju. U 2017. godini industrija videoigara u Sjedinjenim Američkim Državama dosegnula je profit od 36 milijarde dolara (Entertainment Software Association, 2018). Prema podacima Ekonomskog instituta u Zagrebu (2015), hrvatska industrija videoigara raste 50\% godišnje, a IT industrija, kojoj pripada i industrija videoigara, je samo u 2017. godini zabilježila ukupni prihod od 153 milijuna kuna (Hrvatska gospodarska komora, 2018). Stoga, kontinuirano povećanje interesa za videoigre potiče i istraživače da ispituju i definiraju što motivira igrače na neprestani angažman u videoigrama i kakav je njihov učinak na djecu i adolescente (Verhovnik, 2014, str. 306; Przybylski i sur., 2010, str. 154).

Istraživanja na ovu temu do sada su konzistentno ukazivala da učinci videoigara nisu bezazleni (Verhovnik, 2014, str. 303-309; Labaš, 2015, str. 246-247). S jedne strane, znanstvenici i javnost najčešće raspravljaju o negativnim učincima videoigara poput nasilja, prekomjernog igranja i ovisnosti (Verhovnik, 2014, str. 309-312; Bilić, Ljubin Golub, 2011, str. 2), tako da je Melanie Verhovnik (2014, str. 311-314) na temelju raznih istraživanja postavila i pitanje treba li zabraniti videoigre $\mathrm{s}$ nasilnim sadržajima. $\mathrm{S}$ druge strane, istraživanjima se ustanovilo kako videoigre pozitivno utječu na kognitivne sposobnosti - pažnju, pamćenje i kontrolu (Rebetez, Betrancourt, 2007, str. 1), a često se navodi kako igrajući videoigre igrači razvijaju sposobnosti poput koordinacije pokreta, oštrine vida, prostorne orijentacije, pa čak i inteligencije (Bilić i sur., 2010, str. 198). Osim 
toga, veliki se broj znanstvenika bavi proučavanjem informacijske tehnologije kao alata za učenje (Rebetez, Betrancourt, 2007, str. 1) pa se i najstroži kritičari slažu kako igrajući videoigre djeca uče i razvijaju određene vještine, a Florian Stadlbauer (2014, str. 320) govori i o videoigrama s pozitivnim učinkom na učenje. Možda je glavno pitanje: kako iskoristiti moć videoigara na konstruktivan način u našim domovima i školama (Shaffer i sur., 2004, str. 2) i kako odgojiti djecu za kreativnu i odgovornu uporabu novih tehnologija (Parsi, Cantelmi, Orlando, 2009)?

\section{Razlozi za igranje videoigara}

John L. Sherry i Kristen Lucas (2003) su na temelju provedenih istraživanja otkrili šest glavnih motiva zbog kojih ljudi igraju videoigre: 1) natjecanje, s ciljem da igrač bude najbolji u igri; 2) izazov, koji motivira igrača da dođe na sljedeću razinu ili pobijedi u igri; 3) društvena interakcija, sa svrhom igranja s prijateljima i prikupljanja društvenog statusa; 4) razonoda, kako bi prošlo vrijeme ili se ublažila dosada; 5) maštanje, koje potiče igrača da u videoigri radi stvari koje u stvarnom životu ne može; te 6) uzbuđenje i napetost.

Prema istraživanju Andrewa K. Przybylskia i suradnika (2010, str. 154), osnovne potrebe koje igrači nastoje zadovoljiti tijekom igranja videoigara su želja za natjecanjem, autonomijom, interakcijom i dobrim raspoloženjem. No, razlozi koji potiču na igru mogu dovesti i do negativnih posljedica, a ne samo do dobrog raspoloženja (Wimmer, 2014, str. 277-278). Primjerice, videoigre mogu dovesti do povećane agresivnosti nakon igranja, društvenog isključivanja te predugog igranja nasilnih videoigara (Verhovnik, 2014, str. 305-307; Przybylski i sur., 2010, str. 155). Iskustva iz virtualnog svijeta se mogu odraziti i na ponašanje $u$ stvarnom svijetu, kao u slučaju povećane agresivnosti nakon igranja videoigara (Przybylski i sur., 2010, str. 159-162). Istraživači se stoga pitaju što motivira igrače koji igraju videoigre s nasilnim sadržajem, s obzirom na to da nasilje ne zadovoljava temeljne psihološke potrebe (Verhovnik, 2014, str. 307)?

Igranje videoigara prema Florianu Rehbeinu (2011 prema Verhovnik, 2014, str. 306) motivirano je na prvome mjestu željom za zabavom, a ona je potaknuta i mogućnošću igrača da bude aktivan sudionik. Osim toga, Cyril Rebetez i Mireille Bétrancourt (2007, str. 2) uočili su kako unatoč dinamičnome razvoju videoigara, koji je rezultirao njihovom raznolikošću, jedna specifična karakteristika videoigara ostaje nepromijenjena. Naime, 
oni smatraju kako je uronjenost jedan od najvećih razloga popularnosti videoigara. Pojam uronjenosti u virtualni svijet ${ }^{1}$ (engl. immersion) danas se prepoznaje i među igračima videoigara i među znanstvenicima (Piasecki, 2014, str. 283-287), no te dvije zajednice još uvijek nisu suglasne oko značenja pojma i odlučujućih čimbenika koji utječu na njega. Prema istraživanjima, uronjenost $u$ virtualni svijet ili virtualnu stvarnost ${ }^{2}$ je razina sudjelovanja u igri pri čemu se na prvoj razini igraču privuče pažnja (engl. engagement), na drugoj razini je zaokupljen igrom (engl. engrossment), a na zadnjoj, trećoj razini je potpuno uronjen u virtualni svijet (engl. total immersion) (Brown, Cairns, 2004 prema Slivar, 2014, str. 5). Fenomenom uronjenosti također su se bavili Timothy Sanders i Paul Cairns (2010, str. 161) koji su proučavali utječe li uronjenost zaista na psihološku percepciju prolaznosti vremena kod ljudi, pri čemu su uronjenost definirali kao dojam bivanja u igri - pojavu pri kojoj su misli, pažnja i ciljevi osobe usmjereni isključivo na svijet $\mathrm{u}$ igri i okolnosti vezane za igru, a nisu usmjereni ni na što drugo, kao na primjer na ono što se događa u prostoriji u kojoj se nalaze.

\section{Utjecaj medija na primatelje}

Utjecaj medija na primatelje, među kojima su i djeca, bio je i ostao jedan od najzanimljivijih predmeta istraživanja unutar komunikacijskih znanosti koji predstavlja veliki izazov budući da je utjecaj jako teško mjeriti. Melanie Verhovnik (2014, str. 303) ističe da je broj takvih istraživanja jako velik i da ih je nemoguće sve i nabrojiti. No, iz tih je istraživanja jasno da primatelje medijskih poruka „ne treba smatrati isključivo ‘žrtvama’ medijskog utjecaja, nego kao osobe koje su u većoj ili manjoj mjeri sposobne biti aktivnim sudionicima šire shvaćenog medijskog procesa“, naglašava Vlasta Ilišin (2003, str. 13). Ipak valja upozoriti da zbog svakodnevnog korištenja medija primatelji imaju pojednostavljenu predodžbu o djelovanju medija, a posljedica toga je uvjerenje da mogu uvijek ispravno i nepristrano prosuđivati, premda to nije istina (Wimmer, 2014, str. 277-280). Na primjer, ljudi često imaju predodžbu o nasilju u medijima kao opasnosti koja može pogoditi druge, ali ne i njih same. Taj fenomen je u društvenim istraživanjima poznat kao efekt treće osobe, a zapravo se radi o pristranom optimizmu - osjećaju da smo superiorniji od drugih, te potrebi da sebe predstavimo u boljem svjetlu (Kunczik, Zipfel, 2007, str. 2).

1 Virtualan (srednjovj. lat. virtualis: moguć, ostvariv, prema lat. virtus: sposobnost, krjepost, vrlina); koji ne postoji u stvarnosti; nestvaran, izmišljen, prividan (virtualan svijet, virtualan rat) (Enciklopedija.hr, n.p.).

2 Virtualna stvarnost, prividan okoliš simuliran s pomoću računala te posebnih računalnih periferija i programa, unutar kojega je korisniku omogućen privid boravka, kretanja i opažanja (Enciklopedija.hr, n.p.). 


\subsection{Negativan utjecaj videoigara}

Osim ranije spomenutih problema, kao što su nasilje, prekomjerno igranje i ovisnost, istraživanja posljednjih godina su pokazala kako intenzivno igranje videoigara može prouzročiti i neke nove negativne posljedice, poput nedostatka pažnje, impulzivnosti, nedostatka samokontrole i kognitivne kontrole (Prot i sur., 2014, str. 116). U pokušaju pronalaska odgovora na pitanje zašto nasilje u videoigrama utječe na agresivnost primatelja, a najviše na agresivnost djece, Elliot Aronson i suradnici (2005, str. 435) su otkrili neke osnovne reakcije na nasilje u videoigrama koje su, uglavnom, zajedničke djeci: 1) „Ako oni to smiju činiti, smijem i ja.“, 2) „O, tako se to, dakle, radi!“, 3) „Mislim da je ono što sam iskusio/iskusila agresivan osjećaj.“, 4) „Još jedno brutalno premlaćivanje, a što je na drugom kanalu?“ , 5) „Bolje da ja uhvatim njega, prije nego što on uhvati mene!“, a to potvrđuju i druga istraživanja (Koglin, Witthöft, Petermann, 2009 prema Verhovnik, 2014, str. 308).

Prvotna reakcija djece na nasilan sadržaj je strah. Međutim, neprekidnim prikazivanjem nasilja u pozitivnom kontekstu, pomoću zvučnih i vizualnih efekata te nagrada nakon nasilnog djelovanja, primarne se reakcije djece na takav sadržaj smanjuju. Uostalom, prikaz nasilja u kontekstu zabave populariziran je razvojem internetskih videoigara. Takve igre pozivaju na blisku identifikaciju s agresivcima, potiču agresivne misli te pojačavaju frustraciju nakon poraza (Ružić, 2011, str. 19-21). Pritom je vjerojatnost da igrač počne doživljavati virtualni svijet kao stvarnost i primjenjivati virtualno ponašanje i izvan njega veća ako je dublje i dulje uronjen u nj, pa čak dolazi i do desenzibiliziranja i „do smanjenja suosjećanja sa žrtvom“ (Züge, 2008 prema Verhovnik, 2014, str. 308). Izloženost djece nasilnim videoigrama povećava nasilno ponašanje u stvarnom svijetu jer su igrači aktivno uključeni, identificiraju se s likovima te direktno sudjeluju u realističnim nasilnim scenama na koje se navikavaju svakodnevnim igranjem (Carnage i sur., 2007, str. 490-495). Nasuprot tome, ako se smanji vrijeme igranja videoigara, značajno se smanjuje i agresivno ponašanje (Robinson, 2001 prema Verhovnik, 2014, str. 308). No, valja naglasiti da prijenos nasilja iz jednog u drugi svijet nije izravan, nego treba uzeti u obzir različitost virtualne i stvarne okoline te složenost procesa koji se pritom odvijaju (Valković, 2009, str. 501), a na brojne čimbenike na temelju eksperimentalnih istraživanja upozorava i Verhovnik (2014, str. 309-310).

Neki autori upozoravaju i smatraju da je jedan od osnovnih ciljeva kreatora videoigara 
postići što veću ovisnost igrača u svrhu stvaranja profita, ne mareći za moguće posljedice (Mužić, 2014, str. 401). Barlow W. Soper i Mark J. Miller (1983, str. 42) su još prije 20 godina opisali simptome ovisnosti joystick junkieja i kompulzivnog ponašanja: nedostatak interesa za druge aktivnosti, povezivanje s drugim ovisnicima te psihičke i fizičke posljedice u slučaju prestanka igranja. I danas se ovisnost o videoigrama razvija kod prekomjernog igranja videoigara kada „zbog takvih aktivnosti nastanu ozbiljne poteškoće $u$ funkcioniranju osobe u obitelji, društvu i školi te poteškoće u psihološkom funkcioniranju“ (Bilić, Ljubin Golub, 2011, str. 2).

Za razliku od tradicionalnih videoigara koje imaju kraj, ponavljaju se te djeci lako postanu dosadne, igre u online svijetu (poput npr. MMORPG) mogu se igrati beskonačno s ciljem suradnje s ostalim igračima diljem svijeta radi napredovanja u igri. Osim toga, u online svijetu moguće je biti anoniman, upravljati pričom i stvarati različite društvene identitete, što je posebno privlačno igračima koji imaju emocionalne i druge poteškoće (Young, 2009, str. 356). Navedeno je potvrđeno u istraživanju u kojem se ustanovilo da igrači u online svijetu provode više vremena te smatraju virtualne odnose ljepšim nego one izvan interneta. Drugo istraživanje također je dokazalo da što je više vremena provedeno igrajući određenu videoigru na internetu, veća je vjerojatnost da će igrač imati društvene probleme i probleme na poslu ili u školi (Yee, 2006, str. 774). Igranje online igara smatra se problematičnim jer zahtijeva mnogo vremena pa je vjerojatnije da će ovi igrači prije pokazivati simptome ovisnosti negoli oni koji igraju offline (Kuss i sur., 2012, str. 2). Richard Wood (2007, str. 169-173), međutim, smatra da je ovisnost o videoigrama ipak još uvijek manje temeljena na znanstvenim činjenicama, a više na medijskoj histeriji te da pogađa mali broj ljudi, s čime se slaže i Stadlbauer (2014, str. 320) koji navodi da u Njemačkoj čak 93 \% djece i mladih igraju videoigre, ali se videoigrama ne priznaje da imaju i određenu društvenu vrijednost i da podučavaju i o moralnome ponašanju.

U tom je kontekstu nužno naglasiti da, iako su o utjecaju sadržaja videoigara na igrače provedena mnoga istraživanja, i dalje postoji potreba za razumijevanjem onoga što $u$ igri zapravo može imati utjecaj, te što se može učiniti po pitanju uporabe videoigara na prosocijalan način (Züge, 2008 prema Verhovnik, 2014, str. 309; Stadlbauer, 2014, str. 324325). Ako zaključci već pokazuju da videoigre mogu mijenjati igrače, onda prema tome i promjene imaju potencijala za primjenu u ozbiljnije svrhe, poput onih edukativnih (Stadlbauer, 2014, str. 325; Rebetez, Bétrancourt, 2007, str. 2). 


\subsection{Pozitivan utjecaj videoigara}

Videoigre nisu poput ostalih medijskih sadržaja. Korisnik, odnosno igrač videoigara, sukreira priču u igri i sam stvara nove informacije što svaku novu igru čini jedinstvenim iskustvom (Gentile i sur., 2014, str. 121). David Williamson Shaffer i suradnici (2004, str. 4) to iskustvo opisuju kao „sudjelovanje u novim svjetovima“.Videoigre djeci kao igračima omogućavaju da razmišljaju, razgovaraju i djeluju - često i u timu (Züge, 2008 prema Verhovnik, 2014, str. 309). Pružaju im priliku da utjelovljuju likove i igraju uloge koje u stvarnosti ne mogu. Prema tome, virtualni svijet stvara kontekst, a to je ono što videoigre čini potencijalnim, moćnim alatom za stjecanje znanja i novih vještina. Stoga, novija istraživanja o utjecajima videoigara na djecu nastoje dokazati da djeci ne treba zabraniti igranje, nego ih treba usmjeravati prema kvalitetnim sadržajima uz koje će razvijati svoje vještine. Verhovnik (2014, str. 315) stoga ističe: „Zabrane i kontrole praktično i pedagoški su se pokazale kao nedjelotvorne. Zbog toga je potrebna preventivna medijska pedagogija.“

Elizabeth Behm-Moravitz (2013, str. 126) je provela zanimljivu studiju o tome kako, s obzirom na motivaciju za djelovanje unutar virtualnoga svijeta, odabrani identitet avatara može dugoročno donijeti dobrobit za zdravlje, raspoloženje, samopouzdanje i društvene veze. Naime, avatar se reflektira iz virtualnoga u stvarni svijet kao ekstenzija pojedinca te može motivirati na povećanje svijesti o zdravstvenom problemu ili izgledu. Kontroliranje avatara može inspirirati kontrolu nad samim sobom. Slične posljedice uočljive su nakon igranja videoigara s prosocijalnom tematikom u kojima likovi pomažu drugima, ne uključujući nasilje kao sredstvo za postizanje cilja. Dugoročne posljedice mogu se odraziti na povećanje empatije, dijeljenja, suradnje i pomoći među djecom i adolescentima te na smanjenje agresivnog ponašanja (Prot i sur., 2014, str. 121). No, istraživanja o učincima poput dobrog raspoloženja i bolje komunikacije nakon igranja videoigara su ograničena te je potrebno provesti detaljnije i dulje analize (Barlet i sur., 2009, str. 399).

Brojne su studije dokazale da igrači videoigara imaju bolju vizualnu percepciju te da bolje zapažaju detalje od onih koji ne igraju videoigre. Primjerice, studija u kojoj su dvije skupine onih koji inače ne igraju videoigre igrali Tetris i stratešku igru Medal of Honor

3 Avatar, 1. simbolički prikaz sudionika na mreži (prema Laniado, Pietra, 2005); 2. u informatici i komunikacijama, grafika, slika ili tekstovni opis kojim korisnik predstavlja samoga sebe na mrežnim forumima, igrama, u prividnoj stvarnosti i dr. (Enciklopedija.hr, n.p.). 
pokazala je da su igrači strateške igre kasnije imali bolju vizualnu percepciju (Green, Bavelier, 2003 prema Barlet i sur., 2009, str. 388). U slučaju Tetrisa uočeno je poboljšanje u prostornoj orijentaciji jer igrači rotiraju i slažu različite predmete kako bi prikupili bodove (Barlet i sur., 2009, str. 389). Igranje videoigara također može imati pozitivan utjecaj u liječenju nekih bolesti kod djece kao što su astma i dijabetes. Na primjer, igra Bronkie and Bronchiasaurus odvija se u prapovijesnom svijetu punom prašine kojeg treba izbjegavati, a igra Packy Marlon uči djecu načinu života jednog dijabetičara. Igrajući Need for Speed II djeca mogu učvrstiti oštećene dijelove tijela, primjerice mišiće (Kato, 2010 prema RužićBaf, Radetić-Paić, 2010, str. 10). Interaktivne igre koje zahtijevaju neku vrstu vježbanja, poznatije kao exergames, također se mogu koristiti u terapeutske, ali i u druge svrhe koje poboljšavaju fizičko zdravlje (Prot i sur., 2014, str. 122). Sve navedene videoigre djecu podučavaju pozitivnim stavovima s ciljem što boljeg prihvaćanja bolesti (Lieberman, 1997 prema Kosjerina, 2015, str. 8).

Igre postaju sve kompleksnije i sadrže mnoge mehanizme važne za proces učenja (Stadlbauer, 2014), poput raznovrsnih potkrepljenja te njihova različita rasporeda, zatim uparene asocijacije, kognitivne mape, specifične treninge, vježbe i drugo (Gentile i sur., 2014, str. 127). Predrag Zarevski (1997, str. 115) učenje definira kao „proces kojim iskustvo ili vježba proizvode promjene u mogućnostima obavljanja određenih aktivnosti“. Videoigre uistinu nude jedinstveni kontekst $u$ kojemu bi djeca, igrajući videoigre, usvajala znanja i razvijala svoje vještine (Gentile i sur., 2014, str. 127; Stadlbauer, 2014). U skladu s time može se reći kako su videoigre vrsta medija u kojemu korisnik, ne samo da ima priliku djelovati i vidjeti posljedice svojih djela, nego ima priliku i učiti na temelju svojih postupaka (Gentile i sur., 2014, str. 121), posebno kada jer riječ o takozvanim „serious games“ koje sadržajno nude puno više od same zabave (Stadlbauer, 2014, str. 322).

\section{Medijski odgoj: videoigre kao alat za učenje}

Novu tehnologiju i nove medije danas je već nemoguće zaobići pa se smatra da je najbolje naučiti upotrebljavati ju tako da olakšava život te da ga čini bogatijim i kvalitetnijim (Šego, 2009, str. 61). „Cilj novih medija i novih tehnologija je, između ostaloga, i oblikovanje programa i sadržaja za samoučenje i za što kreativnije usvajanje znanja“, ističe Jasna Šego (2009, str. 68-69). Glavna je prednost videoigara, u odnosu na ostale metode učenja, ranije 
istaknuti pripovjedački okvir koji pospješuje i olakšava proces učenja i pamćenja (Piasecki, 2014), za razliku od „suhoparn[ih] stranic[a] neke lekcije iz povijesti“, objašnjavaju Nessia Laniado i Gianfilippo Pietra (2005, str. 48).

Kada je riječ o utjecaju masovnih medija na djecu, Ilišin (2003 prema Uldrijan, 2011, str. 186-187) ističe važnost uloge roditelja u medijskom odgoju: „Iako se škole i nastavnici apostrofiraju kao moderatori dječje medijske osposobljenosti, roditelji i dalje ostaju neizbježnim medijskim socijalizatorima“'. Rezultati istraživanja (Ilišin, Marinović Bobinac, Radin, 2001) provedenog 2000. godine u Hrvatskoj upozoravaju na potrebu djece da dijele svoje dojmove i razmišljanja o onome što su čitala, slušala ili gledala te da razgovaraju sa svojim vršnjacima o tome. Istraživanje je ujedno ukazalo na to da djeca sa svojim roditeljima tek povremeno dijele mišljenja i iskustva iz medijskoga svijeta. Da bi se djeca i mladi snašli u sve većoj i raznovrsnijoj medijskoj ponudi, trebaju od odraslih dobivati smjernice i ugledati se na njihove primjere. Stoga je jasno da medijsku kompetenciju najprije trebaju usavršiti odrasli, što se ponajviše odnosi na roditelje, učitelje i profesore koje je potrebno temeljito educirati (Miliša, Tolić, Vertovšek, 2010, str. 10). Novonastale okolnosti mijenjaju ulogu odgajatelja, učitelja i profesora. Njihov primarni zadatak više nije isključivo prenošenje znanja: „Danas se nastavnik koristi suvremenim medijima i tome poučava druge, analizira, upućuje, savjetuje, potiče na raspravu i autonomno mišljenje, oduševljava učenike za stvaranje“ (Šego, 2009, str. 73).

Sve navedeno ukazuje kako je potrebna promjena odgojnoga stila, tvrdi Ivan Uldrijan (2011, str. 184-185), jer je očito da je u „medijskome svijetu“ više no ikada potrebno razvijati medijsku pismenost i medijske kompetencije. „Stoga je medijski odgoj postao neizostavan dio odgoja djece i mladih, a medijska pismenost, kao rezultat medijskoga odgoja, jedna od najvažnijih pismenosti 21. stoljeća“ (Ciboci, Osmančević, 2015, str. 122), koju treba pospješivati „baš i u školama, budući da se tamo može doći do velikog broja djece i mladih“ (Züge, 2008 prema Verhovnik, 2014, str. 315). 


\section{Metodologija istraživanja}

Predmet ove analize fokusira se na percepciju utjecaja videoigara sa stajališta djece. Podaci koji se koriste rezultat su istraživanja provedenoga između siječnja i ožujka 2016. godine. Za prikupljanje podataka korištena je metoda ankete s otvorenim i zatvorenim pitanjima s ponuđenim odgovorima, Likertovom skalom i skalom procjene (točno-netočno), a odgovori su bili jednostruki i višestruki. Škole obuhvaćene istraživanjem odabrane su na temelju područja u kojemu se nalaze - gradsko, prigradsko i ruralno područje. Osnovni skup iz kojega je odabran uzorak djece činili su učenici osnovnih škola od 5. do 8. razreda, većinom u dobi između 10 i 15 godina koja su odabrana jer su dosadašnja istraživanja ukazala na to da količina i intenzitet igranja najviše dolazi do izražaja u dobi između 8. i 15. godine, što može dati pouzdanije rezultate. Istraživanjem je obuhvaćeno ukupno 630 učenika, od toga 310 dječaka i 311 djevojčica (devet ispitanika u anketnom upitniku nije naznačilo spol). Za testiranje razlika koristile su se četiri nezavisne varijable, odnosno sociodemografski pokazatelji: škola, spol, dob i razred.

S obzirom na prethodno prikazan teorijski pregled i rezultate istraživanja, ovim smo istraživanjem željeli otkriti uočavaju li djeca pozitivne i negativne učinke videoigara, kakve su njihove navike igranja, što ih motivira na igru, kako percipiraju specifična ponašanja uzrokovana igranjem videoigara, te, naposljetku, kakav je njihov stav po pitanju aktivnog korištenja videoigara u edukativne svrhe kod kuće i u školi. Među ostalim, cilj ovoga istraživanja je bio i usporediti navike igranja videoigara i predodžbe o utjecaju videoigara na ponašanje među djecom triju škola s područja Grada Zagreba i Zagrebačke županije. $\mathrm{Na}$ temelju navedenih ciljeva istraživanja postavljene su sljedeće hipoteze:

$H_{1}$ : Djeca nisu svjesna loših učinaka videoigara.

$H_{2}$ : Djeca iz urbanih, prigradskih i ruralnih sredina različito percipiraju učinke videoigara.

$H_{3^{*}}$ Jedni od najčešćih razloga za igranje videoigara su akcija, fantazija, izazov i znatiželja.

$H_{4}$ : Djeca misle da su aktivnosti i ponašanja iz videoigara prihvatljiva i u stvarnosti.

$H_{5}:$ Djeca ne razumiju značenje oznaka upozorenja na omotu videoigara te ih ne znaju točno interpretirati. 
$\boldsymbol{H}_{6}$ : Djeca imaju pozitivan stav prema igranju videoigara u svrhu samostalnog unaprjeđenja ili usavršavanja znanja i sposobnosti.

$H_{7}$ : Djeca vjeruju da će sadržaj videoigara prije negativno utjecati na drugu djecu, nego na njih same, što potvrđuje efekt treće osobe.

\section{Rezultati i rasprava}

Istraživanje provedeno 2010. godine pokazalo je da djeca svoje slobodno vrijeme najviše vole provoditi u igri s prijateljima (Ilišin, 2003), što je također potvrdilo i ovo istraživanje. Međutim, da videoigre uistinu imaju važno mjesto u njihovim životima pokazuje podatak da nakon druženja s prijateljima vani (46,1 \%), djeca svoje slobodne vrijeme najviše vole provoditi igrajući videoigre (18,4 \%) (vidi Grafikon 1). Kao neki drugi način provođenja slobodnoga vremena djeca su navela različite izvanškolske aktivnosti poput treniranja nekog sporta, crtanja, provođenja vremena s obitelji ili igranja s kućnim ljubimcem, a najmanji postotak djece $(5,1 \%)$ svoje slobodno vrijeme provodi čitajući knjige.

Rezultati su pokazali kako gotovo 90 \% djece igra neku vrstu virtualnih videoigara videoigre, računalne igre, internetske ili mobilne igre. Jedan od razloga za to sigurno je dostupnost pametnih telefona, budući da je najviše djece (37,2 \%) izabralo upravo mobitel kao platformu na kojoj najčešće igraju igre. To svakako potvrđuje i podatak da je razvoj videoigara i njihova dostupnost na pametnim telefonima formirala novu zajednicu ljubitelja videoigara - ljubitelja mobilnih igara. Prema tome, porast broja platformi koje omogućavaju igru u virtualnome svijetu rezultirao je povećanjem količine vremena koju djeca danas provode igrajući videoigre. 


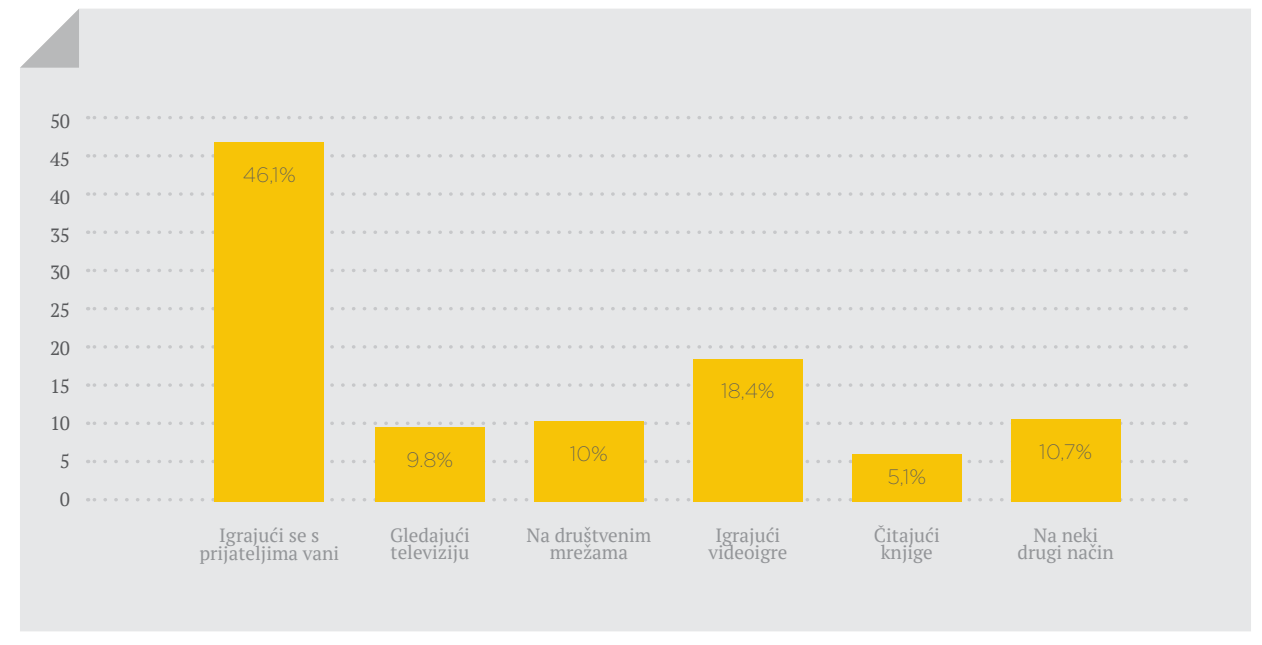

Grafikon 1. Slobodno vrijeme djece $(\mathrm{N}=610)$

Djeca koja igraju videoigre navela su da ih najčešće igraju svakodnevno $(39,4 \%)$, a približno je jednak broj djece odgovorilo da videoigre igra 2 do 3 puta u tjednu $(31,2 \%)$ ili samo vikendom (29,4 \%). Iako polovina ispitane djece videoigre igra manje od jedan sat dnevno, rezultati su ukazali na to kako ipak postoji manja rizična skupina od $4,5 \%$, što čini jedan prosječan razred od 25 učenika, među ispitanicima u tri škole, koji provode više od tri sata dnevno igrajući videoigre. Pritom navode kako igraju od tri pa do čak šest sati dnevno bez prekida, a neki i kroz cijeli dan. Djeca videoigre najčešće igraju kod kuće što potvrđuje postotak od $89,4 \%$.

Većina djece $(59,7 \%)$ ne traži dopuštenje za igranje videoigara od roditelja. Kada je riječ o nadzoru djece tijekom igre, dobiveni podaci (vidi Grafikon 2) pokazuju kako roditelji samo ponekad provjeravaju što njihova djeca igraju i koliko vremena provode igrajući videoigre (36,5 \%). Dio roditelja nikada ne nadzire djecu tijekom igranja videoigara (24,1 $\%)$. Nasuprot tome, rezultati pokazuju da se roditelji ponekad čak i aktivno uključuju u igru (18,2 \%), što je s aspekta medijskoga odgoja najbolji pristup koji u sebi ima ogroman preventivni medijsko-pedagoški potencijal (Verhovnik, 2014, str. 315). 
Ponekad i igraju sa mnom neke videoigre

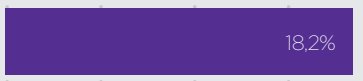

Ne, nikada ne provjeravaju što igram i koliko dugo igram

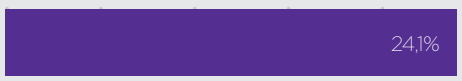

Samo ponekad provjeravaju što igram i koliko dugo igram

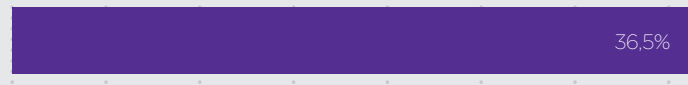

Da, uvijek provjeravaju što igram i koliko dugo igram

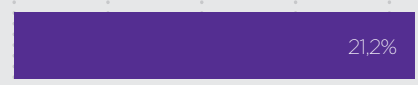

S obzirom na početnu pretpostavku da djeca nisu svjesna loših učinaka videoigara, ispitan je način na koji percipiraju videoigre i uočavaju li dobre i loše strane videoigara. Nešto više od polovice ispitane djece (58,3 \%) vjeruje da su djeca svjesna pozitivnih i negativnih utjecaja sadržaja videoigara. Pritom su većinom (65,4 \%) zaključili kako videoigre nemaju pozitivan utjecaj na djecu. Djeca su svjesna sljedećih negativnih učinaka videoigara (vidi Grafikon 3): ovisnosti zbog prekomjernog igranja (91,4 \%), nerealnog prikaza života i ljudi (87,5 \%), nasilja koje loše utječe na ponašanje (78,4 \%), neprimjerenosti sadržaja videoigara njihovoj dobi (76,9\%), rasprava i svađa među prijateljima (74,3 \%), mogućnosti otkrivanja osobnih i povjerljivih informacija (71,1 \%), te uzroka loših ocjena u školi (62,6 \%). Međutim, djeca su svjesna samo jednog od navedenih pozitivnih učinaka videoigara, a to je suradnja s drugima kako bi se došlo do nekog zadanog cilja. Istodobno, ne prepoznaju pozitivne učinke igranja videoigara, primjerice da igranje videoigara pospješuje koncentraciju i brže rješavanje problema. Prema svemu navedenom, djeca su zapravo svjesna negativnih učinaka sadržaja videoigara više nego li pozitivnih. 


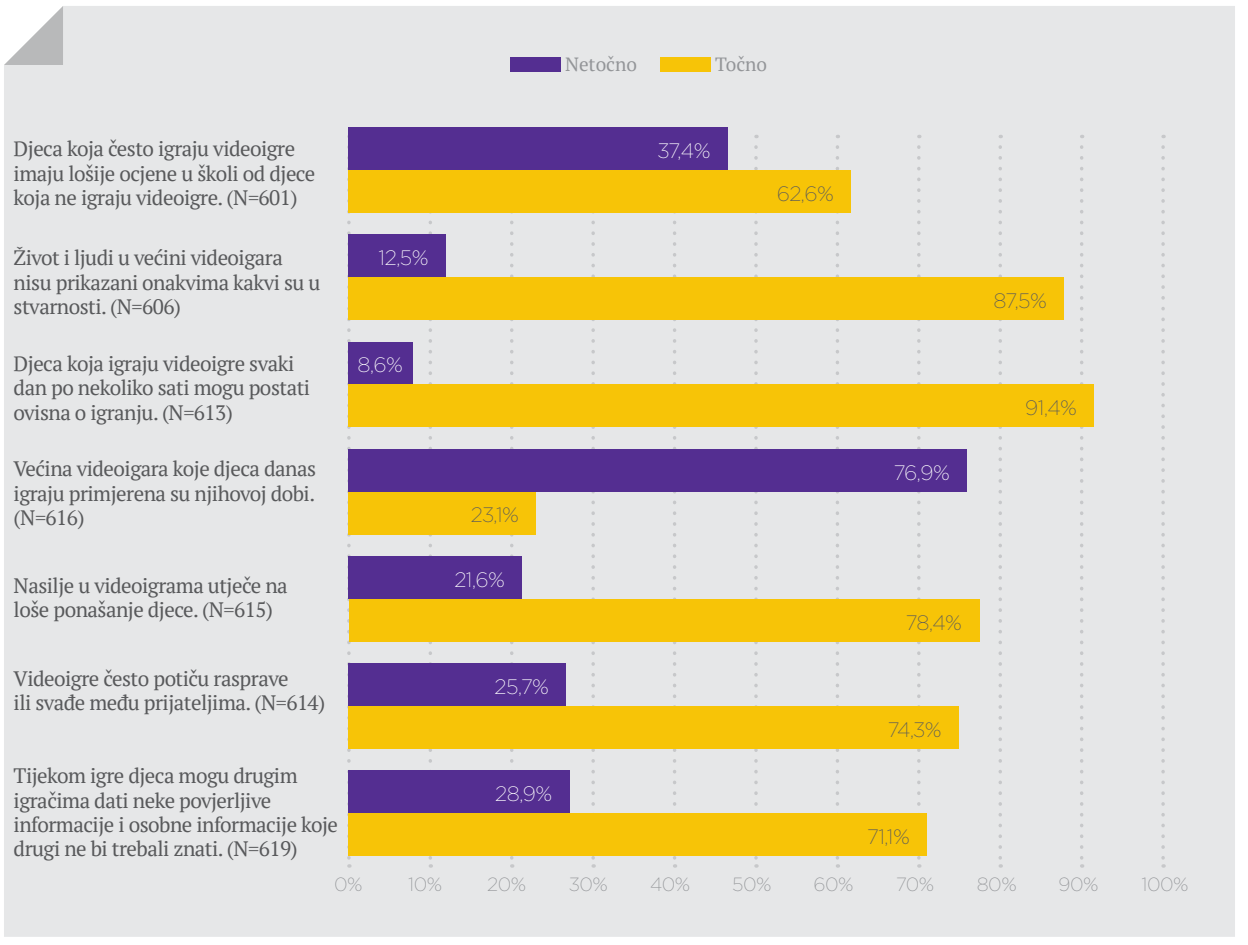

Grafikon 3. Percepcija o utjecaju videoigara na djecu

Nadovezujući se na prethodno podatke važno je naglasiti kako 62,2 \% djece vjeruje da bi videoigre na njih imale pozitivan utjecaj, dok su ranije $u$ anketi naveli kako videoigre generalno negativno utječu na djecu. Kao što je opisano ranije u teoriji, efekt treće osobe pretpostavlja da osobe percipiraju negativne utjecaje kao one koji se više odražavaju na druge nego na njih same (Lin, 2010, str. 208), stoga je ovime potvrđena prisutnost pristranog optimizma, to jest efekta treće osobe.

Motivacija djece za igranjem videoigara ispitana je s pomoću tvrdnji za koje su trebali procijeniti u kojoj se mjeri slažu s njima (vidi Tablicu 1). Pouzdanost mjerne ljestvice analizirana je Cronbach alfa koeficijentom, pri čemu je $\alpha=0,837(\alpha>0,7)$ što ukazuje na pouzdanost mjerne ljestvice. Zabava se kroz više pitanja istaknula kao osnovni motiv za igranje videoigara - 37,8 \% djece potpuno se slaže s tvrdnjom da su videoigre dobar način zabave, s kojima donekle stav dijeli 36,2 \% ispitane djece. No, promatrajući Tablicu 
1 vidljivo je da, osim zabave, do izražaja dolazi još nekoliko motiva. Izazov je, prema dobivenim rezultatima, jedan od najjačih motiva za igru s obzirom na to da $76,7 \%$ djece videoigre smatra zabavnim zbog izazova. Da videoigre potiču znatiželju u potpunosti ili donekle složilo se ukupno 64,3 \% djece. Zbog malih razlika među postocima u vezi tvrdnje da su najbolje videoigre pune akcije, teško je izdvojiti određeni stav. Možemo sa sigurnošću reći da je to jedan od važnijih motiva, no da nije i ključan. Djeca su također potvrdila da im videoigre omogućavaju proživljavanje situacija koje se u stvarnosti ne doživljavaju svakodnevno, a nešto više od 50 \% djece se potpuno ili donekle složilo $\mathrm{s}$ tvrdnjom da videoigre omogućavaju utjelovljivanje likova (osoba) koji u stvarnosti ne mogu biti.

Da među djecom prevladava pozitivan stav prema likovima u virtualnom svijetu potvrđuje postotak od 52,8 \% djece koja su se u potpunosti ili donekle složila s tvrdnjom kako im videoigre omogućavaju da budu netko ili nešto što u stvarnosti nisu ili ne mogu biti. Zatim, većina $(65,9 \%)$ se djece - kao što smo rekli - slaže da videoigre omogućavaju proživljavanje situacija koje se u stvarnosti ne proživljavaju svaki dan, a čak 76,2 \% djece smatra kako igranje videoigara može rezultirati formiranjem pozitivnog stava prema suradnji s drugima i timskom radu s ciljem ostvarivanja nekog rješenja. Shodno tome, postoji mogućnost da djeca aktivnosti svojih omiljenih virtualnih likova odobravaju ili pak oponašaju. Nasuprot tome, kada je riječ o prijenosu viđenih aktivnosti ili ponašanja iz virtualnog u stvarni svijet, istraživanje je pokazalo kako djeca ne podržavaju nasilna ponašanja u videoigrama. To potvrđuje postotak od 78,4 \% djece koja su se složila da nasilje u videoigrama utječe loše na ponašanje djece. 


\begin{tabular}{|c|c|c|c|c|}
\hline Tvrdnja & $\begin{array}{l}\text { Potpuino } \\
\text { se slažem }\end{array}$ & $\begin{array}{l}\text { Niti se } \\
\text { slažem niti } \\
\text { se ne slažem }\end{array}$ & $\begin{array}{l}\text { Uglavnom } \\
\text { se ne } \\
\text { slažem }\end{array}$ & $\begin{array}{l}\text { Uopće } \\
\text { se ne } \\
\text { slažem }\end{array}$ \\
\hline Videoigre potiču znatiželju. $(\mathrm{N}=617)$ & $35,5 \%$ & $21,2 \%$ & $7,1 \%$ & $7,3 \%$ \\
\hline $\begin{array}{l}\text { Videoigre omogućavaju proživljavanje } \\
\text { situacije koje u stvarnosti ne doživljavamo } \\
\text { svaki dan. }(\mathrm{N}=607)\end{array}$ & $34,3 \%$ & $17 \%$ & $8,7 \%$ & $8,4 \%$ \\
\hline $\begin{array}{l}\text { Igranje videoigara je dobar način za } \\
\text { stvaranje novih prijateljstava. }(\mathrm{N}=615)\end{array}$ & $12,4 \%$ & $22,6 \%$ & $17,4 \%$ & $27,8 \%$ \\
\hline $\begin{array}{l}\text { Videoigre su zabavne jer su pune izazova. } \\
(\mathrm{N}=609)\end{array}$ & $44,2 \%$ & $12,8 \%$ & $6,2 \%$ & $4,3 \%$ \\
\hline $\begin{array}{l}\text { Videoigre omogućavaju da budemo netko/ } \\
\text { nešto što u stvarnosti nismo ili ne možemo } \\
\text { biti. }(\mathrm{N}=608)\end{array}$ & $28,6 \%$ & $17,9 \%$ & $12 \%$ & $17,3 \%$ \\
\hline Najbolje videoigre su pune akcije. $(\mathrm{N}=614)$ & $22,2 \%$ & $23,6 \%$ & $13,5 \%$ & $19,2 \%$ \\
\hline Videoigre su dobar način zabave. $(\mathrm{N}=624)$ & $37,8 \%$ & $17,8 \%$ & $5,8 \%$ & $2,4 \%$ \\
\hline
\end{tabular}

Djeca su u anketi također trebala protumačiti značenja oznaka upozorenja koje se nalaze na omotu videoigara (vidi Sliku 1). Oznake upozorenja, poznate još i kao PEGI alati, osmišljene su u sklopu softvera PEGI (The Pan-European Game Information) s ciljem klasifikacije videoigara prema uzrastu djece i primjerenosti sadržaja u videoigrama te informiranja - prije svega roditelja - o donošenju odluka pri kupnji videoigara (RužićBaf, Radetić-Paić, 2010, str. 12). Predočene su četiri oznake upozorenja: 12+ godina, 18+ godina, igra koja sadrži elemente nasilja te igra koja sadrži vulgarne izraze. Za svaku pojedinu oznaku bila su ponuđena tri odgovora. S obzirom na to da je u svakome od četiri ponuđena primjera bilo više od 80 \% točnih odgovora, može se reći kako djeca prepoznaju i pravilno tumače oznake. Osim toga, djeca obuhvaćena istraživanjem očito razumiju $(76,9 \%)$ kako većina danas popularnih videoigara nisu primjerena njihovoj dobi. Međutim, unatoč prepoznavanju upozorenja djeca i dalje igraju neprimjerene videoigre što ukazuje na to da klasifikacija prema uzrastu i primjerenosti sadržaja nije dovoljna da bi se djecu zaštitilo od negativnih učinaka sadržaja videoigara, o čemu smo pisali i u teorijskom dijelu ovoga rada (Verhovnik, 2014).

4 Sustav PEGI detaljno je razrađen i objašnjen u brošuri „Svijet videoigara“ koju je priredilo Društvo za komunikacijsku i medijsku kulturu 2014. godine. 

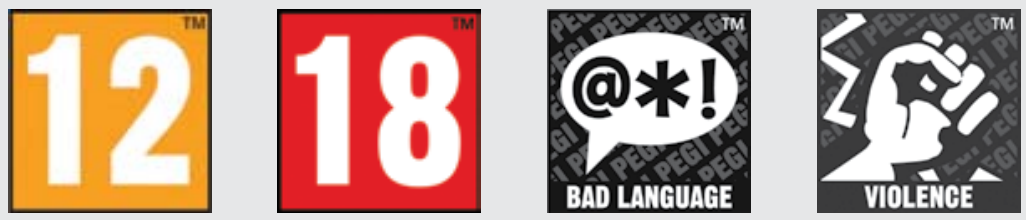

Slika 1. Oznake upozorenja iz ankete

Nadalje, samo 12,2 \% ispitane djece nikada nije igralo edukativnu videoigru, odnosno računalnu, internetsku ili mobilnu igru. Po pitanju uporabe videoigara kao alata za učenje, ponavljanje, rješavanje zadaće ili pripremanje za provjeru znanja, približno je jednak postotak djece koja bi ih željela koristiti u navedene svrhe te koja to ne bi željela. Naime, nešto više od polovice djece $(54,4 \%)$ iskazalo je želju za uporabom videoigara s ciljem samostalnog usvajanja nastavnog gradiva, a gotovo isti postotak $(53,1 \%)$ djece misli kako bi se videoigre mogle koristiti i u nastavi za učenje. Dakle, vidljivo je da djeca videoigre ne smatraju isključivo alatom za zabavu, već u njima prepoznaju priliku za usvajanje ili usavršavanje znanja i vještina. Navedeno dokazuje 53,7 \% djece koja su se, u potpunosti ili djelomično, složila s tvrdnjom kako igrajući videoigre djeca mogu poboljšati svoj način razmišljanja, zaključivanja, reakcije i druge sposobnosti, što su potvrdila i ranija istraživanja (Vimmer, 2014, str. 275). Djeca također vjeruju da igrajući videoigre mogu naučiti korisne stvari kao npr. poboljšati znanje iz engleskog jezika, bolje se služiti računalom, smišljati strategije ili razviti kreativnost (88,5 \%).

U svrhu testiranja hipoteze i zbog usporedbe rezultata prema trima različitim područjima, odnosno školama testirana je nulta hipoteza koja glasi: Ne postoji značajna razlika u percepciji učinaka videoigara među učenicima iz gradskih, prigradskih i ruralnih sredina. Značajnost razlika među trima skupinama unutar uzorka ispitana je ANOVA testom, a rezultati su pokazali kako ne postoji značajna razlika u stavovima među učenicima pojedinih škola bez obzira nalazi li se škola $u$ gradu, predgrađu ili periferiji ( $p>0,05)$. U slučaju svake pojedine škole preko 85 \% djece igra neku vrstu virtualnih igara. U svakoj 
školi više od polovice ispitanih učenika vjeruje da su djeca svjesna pozitivnih i negativnih utjecaja videoigara. Primjerice, u OŠ Petar Zrinski, koja se nalazi u centru grada Zagreba, i OŠ Velika Mlaka, koja se nalazi izvan grada, čak jednak postotak (64,3 \%) učenika smatra kako videoigre imaju pozitivan utjecaj na djecu. Također, očigledno je da su stavovi djece gotovo identični po pitanju utjecaja videoigara na njih same. U svakoj školi više od $60 \%$ učenika vjeruje kako bi videoigre na njih imale prije pozitivan, nego li negativan utjecaj.

\section{Zalključalk}

Porast broja platformi koje omogućavaju igru u virtualnome svijetu rezultirao je povećanjem količine vremena koju djeca danas provode igrajući videoigre (Stadlbauer, 2014, str. 320). Sukladno tome, djeca su danas izložena pozitivnim i negativnim učincima videoigara više no ikada prije. Iako su u velikoj mjeri svjesna pozitivnih i negativnih učinaka, još uvijek ne prepoznaju sve negativne i pozitivne strane videoigara te izazove koje im pruža igra u virtualnome svijetu. Djeca smatraju kako će videoigre prije ostaviti negativan, nego li pozitivan utjecaj na djecu općenito. No, to ne vrijedi kada je riječ o njima samima jer u tom slučaju većina ih se smatra manje osjetljivima na negativne podražaje iz videoigara. Osim toga, činjenica je kako je raznovrsnost videoigara i mnogobrojnost platformi za igranje posljedica nezaustavljivog napretka tehnologije i medija koji, osim brojnih rizika, pružaju i razne prednosti među kojima su učenje i razvoj novih vještina. Rezultati istraživanja pokazali su kako većina djece uviđa mogućnost upotrebe videoigara u edukativne svrhe. Unatoč prepoznavanju većine negativnih posljedica intenzivnog igranja, zabava se pokazala kao dovoljno snažan motiv koji ih zadržava u igri. Ono što ih najviše zabavlja u igrama je izazov (44,2 \%), zatim znatiželja (35,5 \%) i fantazija (34,3 \%) koja im omogućava proživljavanje nesvakidašnjih situacija te, naposljetku, akcija (23,6 \%). Upravo bi se ti motivi mogli u budućnosti iskoristiti kao temelj za daljnji razvoj edukativnih igara.

Djeca su svjesna s kakvim se medijskim sadržajem suočavaju tijekom igranja što dokazuje razumijevanje značenja PEGI oznaka. Regulacija sadržaja postoji, no oznake upozorenja na videoigrama očito ih ne ograničavaju dovoljno. Zbog svoga uvjerenja kako negativan sadržaj ne može ostaviti posljedice na njih, djeca uglavnom oznake ne uvažavaju. Dakle, 
nije dovoljna samo regulacija, potrebna je i prevencija, na što smo upozorili u ovome radu (Verhovnik, 2014). Naime, djeca učestalo i u velikoj količini provode svoje slobodno vrijeme u svijetu videoigara, a većina ih najviše igra upravo kod kuće. Pretpostavka je da s roditeljima komuniciraju o svojim aktivnostima pa tako i igranju videoigara, odnosno o svemu onome što svakodnevno gledaju i slušaju. Međutim, istraživanje je pokazalo kako samostalno odlučuju kada će i hoće li igrati videoigre. Većina djece ne pita roditelje za dopuštenje prije nego što započnu s igrom, a istodobno većina roditelja rijetko provjerava što djeca igraju i koliko zapravo vremena provode igrajući videoigre. Velika je odgovornost na roditeljima. Zbog toga je važno educirati ne samo djecu o medijima i njihovu utjecaju, već je važno educirati i roditelje koji bi im, osnaživši svoje medijske kompetencije, trebali osigurati zaštitu od mogućih prijetnji i rizika medijskih sadržaja.

U proces medijskog opismenjavanja također bi trebali biti uključeni i nastavnici. Educirani roditelji, učitelji i profesori bi zatim svojim primjerima i smjernicama mogli pomoći djeci pri odabiru videoigara s pomoću kojih bi se samostalno i aktivno mogli uključiti u proces učenja, lakše usvajati nastavno gradivo te poticati kreativnost i praktično primjenjivati znanje.

\section{Popis literature}

- Aronson, E., Wilson T., Akert, R. (2005). Socijalna psihologija. Zagreb: MATE.

- Barlet, C. P., Anderson, C. A., Swing, E. L. (2009). Video Game Effects - Comfirmed, Suspected, and Speculative. A Review of the Evidence, Simulation \& Gaming, 40 (3), 377-403.

- Behm-Moravitz, E. (2013). Mirrored selves: The influence of self-presence in a virtual world on health, appearance, and well-being. Computer in Humans Behavior, 29 (1), 119-128.

- Bilić, T., Ljubin Golub, V. (2011). Patološko igranje videoigara: uloga spola, samopoštovanja i edukacijske sredine. Hrvatska revija za rehabilitacijska istraživanja, 47 (2), 1-13.

- Bilić, V., Gjukić, D., Kirinić, G. (2010). Mogući učinci igranja računalnih igrica i videoigara na djecu i adolescente. Napredak, 151 (2), 195-213.

- Brown, E., Cairns, P. (2004). A grounded investigation of game immersion. CHI '04 extended abstracts on Human factors in computing systems, istraživački izvještaj. Dostupno na: http://complexworld.pbworks.com/f/ Brown+and+Cairns+\%282004\%29.pdf. Preuzeto 18. siječnja 2016.

Carnagey, N. L., Anderson, C. A., Bushman, B. J. (2007). The effect of video game violence on physiological desensitization to real-life violence. Journal of Experimental Social Psychology, 43, 489-496.

- Ciboci, L., Osmančević, L. (2015). Kompetentnost nastavnika hrvatskog jezika za provođenje medijske kulture u hrvatskim osnovnim školama, 121-139. U: Car, V., Turčilo, L., Matović, M. (ur.), Medijska pismenost - preduvjet za odgovorne medije. Sarajevo: Fakultet političkih nauka Univerziteta u Sarajevu.

- Ekonomski institut (2015). Mapiranje kreativnih i kulturnih industrija u Republici Hrvatskoj, Projektna studija. 
Dostupno na: http://hkkkki.eu/dokumenti/mapiranje.pdf. Preuzeto 31. siječnja 2019.

- ESA - Entertainment Software Association (2018). Essential facts about the computer and video games industry. Dostupno na: http://www.theesa.com/wp-content/uploads/2018/05/EF2018_FINAL.pdf. Preuzeto 31. siječnja 2019.

- Felicia, P. (2009). Digitalne igre u školama - Priručnik za učitelje. Bruxelles: European Schoolnet.

- Gentile, A. D., Groves, C., Gentile, R. (2014). The general learning model: unveiling the teaching potential of video games, 121-142. U: Blumberg F. C. (ur.), Learning By Playing: frontiers of video gaming in education. New York: Oxford University Press.

- Green, C. S., Bavelier, D. (2003). Action video game modified visual selective attention. Nature, 423 (6939), $534-537$.

- Hammelmann, P., Stadlbauer, F. (2014). Spielen mit Lerneffekt. Spieleentwickler Florian Stadlbauer über Potentiale und Grenzen seiner Branche. Communicatio Socialis, 47 (3), 320-327.

- Hrvatska gospodarska komora (HGK) (2018). Analiza hrvtske IT industrije 2008. - 2017. Dostupno na: https://www. hgk.hr/documents/analizahrvatskeitindustrije5c372c1f59ebb.pdf. Preuzeto 31. siječnja 2019.

- Ilišin, V. (2003). Mediji u slobodnom vremenu djece i komunikacija o medijskim sadržajima. Medijska istraživanja, $9(2), 9-34$.

- Kato, M. P. (2010). Video game sin Health Care: Closing the Gap. Review of General Psyhology, 14 (2), $113-121$.

- Kebritchi, M., Hirumi, A., Bai, H. (2008). The Effects of Modern Math Computer Games on Learners'Math Achievement and Math Course Motivation in a Public High School Setting. Istraživački izvještaj. Dostupno na: http://wsfcs.k12.nc.us/ cms/lib/NC01001395/Centricity/Domain/2144/u_of_central_florida_research_b rief.pdf. Preuzeto 18. ožujka 2016.

- Kosjerina, A. (2015). Pozitivni i negativni utjecaji igranja videoigara - pregled istraživanja. Zagreb: Sveučilište u Zagrebu.

- Kunczik, M., Zipfel, A. (2007). Mediji i nasilje: aktualno stanje u znanosti. Medianali, 1 (1), 1- 26.

- Kuss, D. J., Louws, J., Wiers, R. W. W. (2012). Online gaming addiction? Motives predict addictive play behavior in Massively Multiplayer Online Role-Playing Games. Cyberpsychology, Behavior \& Social Networking, 15 (9), $480-485$.

- Labaš, D. (2015). Nasilje u medijima, 229-248. U: Nikić, M., Marjanović, M. (ur.), Religije i nasilje, Zagreb: Filozofskoteološki fakultet Družbe Isusove.

- Laniado, N., Pietra, G. (2005). Naše dijete, videoigre, internet i televizija - što učiniti ako ga hipnotiziraju?. Rijeka: Studio TiM.

- Lieberman, D. A. (1997). Interactive video games for health promotion: Effects on knowledge, self-efficacy, social support, and health, 103-120. U: Gold, R., Mannings, T. (ur.), Health promotion and Interactive technology: Theoretical applications and future directions. New York: Lawrence Erlbaum Associates.

- Lin, S. (2010). Perceived Influence od negative and positive video game. Journal of Media and Communication Studies, 2 (10), 208-214.

- Miliša, Z., Tolić, M., Vertovšek, N. (2010). Mladi - Odgoj za medije: priručnik za stjecanje medijskih kompetencija. Zagreb: M.E.P. d.o.o., Zadar: Udruga CINAZ.

- Mužić, J. (2014). Štetan utjecaj virtualnog svijeta na djecu. Obnovljeni život, 69 (3), 395-404.

- Parsi, M. R., Cantelmi, T., Orlando, F. (2009). L'immaginario prigioniero. Come educare i nostri figli a un uso creativo e responsabile delle nuove tecnologie. Milano: Arnaldo Mondadori Editore - San Paolo.

- Piasecki, S. (2014). Das Kreuz mit dem Game. Warum die Religion im Videospiel stärkere Beachtung verdient. Communicatio Socialis, 47 (3), 283-301.

- Prot, S., Anderson, C. A., Gentile, D. A., Brown S. C., Swing, E. L. (2014). The Positive and Negative Effects of Video Game Play, 109-128. U: Jordan, A., Romer, D. (ur.), Media and the Well-Being of Children and Adolescent. England: Oxford Univeersity Press.

- Przybylski, A. K., Rigby, C. S., Ryan, R. M. (2010). A motivational model of video game engagement. Rewiev of General Psychology, 14 (2), 154-166. 
- Rebetez, C., Betrancourt, M. (2007). Video game research in cognitive and educational sciences. Cognition, Brain, Behaviour, 11 (1), 131-142.

- Ružić-Baf, M., Radetić-Paić, M. (2010). Utjecaj računalnih igara na mlade i uporaba PEGI alata. Život i škola, 56 (24), 9-18.

- Ružić, N. (2011). The Internet and Video Games: Causes of Increased Aggressiveness among Young People. Media Studies, 2 (3-4), 16-28.

- Sanders, T., Cairns, P. (2010). Time perception, immersion and music in videogames. Proceedings of the 24th BCS Interaction Specialist Group Conference. United Kingdom: British Computer Society, 160-167.

- Sandford, R., Williamson, B. (2004). Racing Academy. Istraživački izvještaj. Dostupno na: https://www.nfer.ac.uk/ publications/FUTL44/FUTL44.pdf. Preuzeto 18. ožujka 2016.

- Shaffer, D. W., Squire, K. R., Halverson, R., Gee, J. P. (2004). Video games and the future of learning. Wisconsin Center for Education Research, Madison: University of Wisconsin.

- Sherry, J. L., Lucas, K. (2003). Video Game Uses and Gratifications as Predicators of Use and Game Preference, 213224. U: Bryant, J., Vorderer, P. (ur.), Playing video games: Motives, responses, consequences. Mahwah, New Jersey: Lawrence Erlbaum Associates.

- Slivar, I. (2014). Iskustvena kvaliteta mrežnih igara. Zagreb: Sveučilište u Zagrebu.

- Soper, W. B., Miller, M. J. (1983). Junk time junkies: An emerging addiction among students. School Counsellor, 31 (1), 40-43.

- Šego, J. (2009). Obrazovanje za medije - doprinos medijskoj kompetentnosti i kulturi odgovornosti, 61-75. U: Labaš, D. (ur.), Novi mediji - nove tehnologije - novi moral. Zagreb: Hrvatski studiji.

- Tvornica istraživanja (2014). Koliko godišnje igramo videoigre. Dostupno na: http://www.tvornicaistrazivanja.hr/ koliko-godisnje-igramo-video-igre/. Preuzeto 28. veljače 2016.

- Uldrijan, I. (2011). Zašto odgajati za medije? Mediji kao odgojitelji u doba odgojne krize, 173-192. U: Labaš, D. (ur.), Komunikacija i mediji u krizi. Zagreb: Hrvatski studiji.

- Valković, J. (2009). Karakteristike i djelovanje nasilja u videoigrama. Riječki teološki časopis, 32 (2), 483-502.

- Verhovnik, M. (2014). Alles nur ein Spiel? Gewalt in Computer und Videospielen und ihre Wirkung. Communicatio Socialis, 47 (3), 302-319.

- Wimmer, J. (2014). Moralische Dilemmata in digitalen Spielen. Wie Computergames die ethische Reflexion fördern können. Communicatio Socialis, 47 (3), 274-282.

- Wood, R. T. A. (2007). Problems with the Concept of Video Game 'Addiction': Some Case Study Examples. International Journal of Mental Health Addiction, 6 (2), 169-178.

- Yee, N. (2006). Motivations for play in online games. CyberPsychology \& Behavior, 15 (9), 772-775.

- Young, K. (2009). Understanding Online Gaming Addiction and Treatment Issues for Adolescents. The American Journal of Family Therapy, 37 (5), 355-372.

- Zarevski, P. (1997). Psihologija pamćenja i učenja. Jastrebarsko: Naklada Slap. 


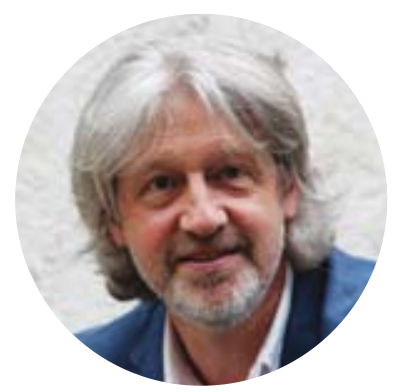

Danijel Labaš

Prof. dr. sc. Danijel Labaš redoviti je profesor na Odsjeku za komunikologiju Hrvatskih studija Sveučilišta u Zagrebu. Autor i urednik više knjiga i zbornika, kao i znanstvenih i stručnih članaka, posebno $\mathrm{s}$ područja medijske pismenosti i etike. Član je Hrvatskog povjerenstva za suradnju s Organizacijom ujedinjenih naroda za prosvjetu, znanost i kulturu (UNESCO), Matice hrvatske i Hrvatskog društva katoličkih novinara. Od 1998. predsjedava žirijem Glasa Koncila koji na Danima hrvatskog filma dodjeljuje filmsku nagradu za promicanje etičkih vrijednosti na filmu Zlatna uljanica, te autor i voditelj emisije Okrugli stol Trećega programa Hrvatskog radija. Predsjednik je Društva za komunikacijsku i medijsku kulturu i voditelj krovnog projekta Djeca medija, te je jedan od organizatora i suvoditelj Komunikološke škole Matice hrvatske.

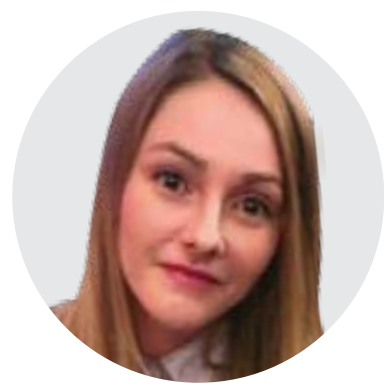

\section{Ines Marinčić}

Ines Marinčić je magistrirala na Hrvatskim studijima na Odsjeku za komunikologiju, smjer odnosi s javnošću. Tijekom studija stekla je iskustvo u području marketinga i odnosa s javnošću. Radi u Institutu za razvoj i inovativnost mladih kao voditelj nacionalnih i europskih projekata iz područja obrazovanja i STEM-a gdje sudjeluje $u$ cjelokupnom projektnom ciklusu: pisanju, vođenju i izvještavanju. Članica je Društva za komunikacijsku i medijsku kulturu gdje je u projektu Djeca medija bila predavač djeci osnovnoškolskog uzrasta o temama medijske pismenosti. Dobitnica je nagrade Hrvatske udruge za odnose s javnošću Mlada nada PR-a za 2017. godinu.

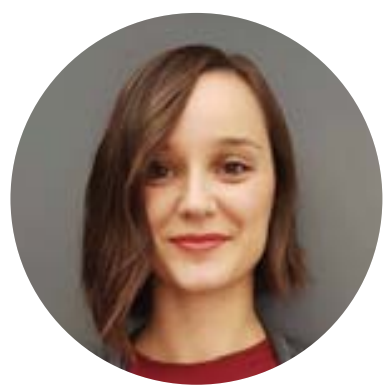

\section{Alma Mujčinović}

Alma Mujčinović je magistrirala na Hrvatskim studijima na Odsjeku za komunikologiju na temu Kvaziznanstvenost na primjeru suvremenih hrvatskih reklama za lijekove bez recepta. Tijekom studija vršila je funkciju studentice demonstratorice na nekoliko različitih kolegija, te je stekla iskustvo u području marketinga sudjelujući i vodeći razne projekte. Članica je Društva za komunikacijsku i medijsku kulturu kroz čije je projekte stekla znanje $\mathrm{i}$ iskustvo $\mathrm{u}$ području medijske pismenosti. Trenutno radi kao Account Executive u kreativnoj marketinškoj agenciji Saatchi \& Saatchi Croatia. 